American Research Journal of Humanities and Social Sciences

(ARJHSS)

ISSN (Online) : 2378-7031

AMERICAN RESEARCH JOURNALS

Volume 2, 2016, 1- 6 pages

An Academic Publishing Fouse

DOI: $10.21694 / 2378-7031.16015$

Research Article

Open Access

\title{
Personal Ideology of Curriculum
}

\author{
Ibrahim Alfarhan \\ Graduate Student, School of Education \\ Saint Louis University, St. Louis, United States \\ Ibrahim_uni@hotmail.com
}

\begin{abstract}
Some students may be learning the lesson quite well, while others are missing key concepts and falling behind because they lack prerequisite skills for new learning" (Slavin. 2008). Curriculum, along with instructions and teachers are the three dimensions by which fine products, students, can be produced. In this paper, the researcher will withdraw some important points that are beneficial in order to make a clear understanding of curriculum ideology.
\end{abstract}

Keywords: Personal Ideology, Curriculum, Human Experience, Student's Prior Knowledge, Assessments, Role of the Learner, Role of the Teacher, Professional Practices.

\section{PURPOSES FOR CURRICULUM}

"The one continuing purpose of education, since ancient times, has been to bring people to as full a realization as possible of what it is to be a human being. Other statements of educational purpose have also been widely accepted: to develop the intellect, to serve social needs, to contribute to the economy, to create an effective work force, to prepare students for a job or career, to promote a particular social or political system. These purposes offered are undesirably limited in scope, and in some instances they conflict with the broad purpose I have indicated; they imply a distorted human existence. The broader humanistic purpose includes all of them, and goes beyond them, for it seeks to encompass all the dimensions of human experience." (Foshay, summer, 1991). I have this quotation always in front of me whenever I was asked the question: What is the purpose of education? I have asked this question to many of my students and teachers. Their answers differs according to their requirement of teaching and learning. I believe that the purpose of curriculum is to end up with a fine product, student, who can serve the society in the most beneficial way, as what I am doing here. My plans is to go back and pay back my country and society who believed in me.

\section{ESSENTIAL CONDITIONS FOR LEARNING}

Learning takes place mostly as a result of learners' practices of the behavior they are to learn. In other words, learning result of intentional activity initiated by the teacher and deliberately aimed to the students. Prior to these activities, there should be an understanding achieved by the teacher of the prerequisite skills required for these particular skills. As stated previously, "some students may be learning the lesson quite well, while others are missing key concepts and falling behind because they lack prerequisite skills for new learning" (Slavin. 2008). Three elements that can help learning to take place and they are as follows:

Objectives: "Education that prepares for life is one that prepares for the specific activities. The curriculum will then be that series of experiences which children and youth must have by way of attaining those objectives... that series of things which children and youths must do and experience by way of developing abilities to do the things well that make up the affairs of adult life; and to be in all respects what adults should be." (Bobbitt, 1918:42). These objectives are to be sequenced according to a hierarchical design where students 
start practicing from easy- complex- more complex tasks. Finally, the product, the student, is ready to take his role in society. Finally, Social Efficiency supporters believe objectives should be stated in behavioral terms (observable skills, capabilities for action, activities, etc.)

Student's prior knowledge: There should be a clear understanding by the teacher of the student's prior knowledge to know where to start. In many theoretical studies, it was proven that reading comprehension (in many subject areas, not just language arts) increases when background knowledge about that reading content is involved (Graves \& Cook, 1980).

Assessments: According to the Department of Basic Education (2010:53), "formal assessment provides teachers with a systematic way of evaluating how well students are progressing in a grade and a particular subject. Formal assessment tasks are recorded and used to determine whether students should be promoted to the next grade".

The primary consideration for developing and offering SLE learning must be founded on the needs of the educational community within which it is to be taught. There are six fundamental questions to be answered before courses may be offered, they are:

1. Why - why is there a need?

2. What - what will be taught?

3. Who - who will teach and who will learn?

4. When - when should classes begin - at what age?

5. Where - where should learning take place - at home, in class, or within the general population?

6. How - how will the program be developed, offered, graded, updated and supervised?

These questions will recur throughout every stage of an effective educational program, but doubtless more so in SLE due to collective societal challenges that may occur. This is not to be viewed negatively as with challenge comes thought, ideas and creation.

During my teaching career, I've noted one truth; students no longer want to led and fed information like sheep. They are taking an interest in their education and their future by wanting to participate in the development and application of improved curricula - Voice in their future.

I believe the most efficient instructional model for teaching English as a Second Language (ESL) must begin with addressing the needs of a single class of students. This being the microcosm of a particular educational community with continuing consideration for the macrocosm, the society in general. This can only be accomplished via the establishment of concise objectives for curriculum, student, educator and administrator which will ultimately produce the target goal of an exceptionally educated and successful student.

Although the requirements of the populace-at-large will remain pre-eminent, it is understood that for SLE to be successful, it will command full cooperation from all participants and the educational community proper.

\section{BELIEFES ABOUT THE ROLE OF THE LEARNER}

"Instruction is guided by clearly defined behavioral objectives, and learners may require a lot of practice to gain and maintain mastery of skills" (Schiro, 2012). Schiro places an emphasis on a generalization that all students may learn in a prescribed manner if allowed sufficient time and incentive to do so.

Moreover, The presence of prerequisite skills is the basis of academic readiness. If students are not learning, it might be because of invalid assumptions about prerequisite skills that the teacher assumed children have. 
In other words "A particular lesson might be too advanced for a particular group of students, or it may be that some students already know the material being taught. Some students may be learning the lesson quite well, while others are missing key concepts and falling behind because they lack prerequisite skills for new learning" (Slavin. 2008).

In terms of instruction, as well, students should be exposed to an appropriate level of instruction to make sure that they already have the prerequisite skills required for the next learning task. "In theory, mastery learning should provide appropriate levels of instruction by ensuring that students have mastered prerequisite skills before they receive instruction in subsequent skills." (Slavin, 1987)

In terms of the learners' involvment, I believe that they should be given an opportunaty to choose if possible. For example, if the target objective is to teach them reading, the teacher may give his students an opportunaty to choose their readings according to their interests. By that, they will fell incuraged to finish the task with something related to them. Also, the reading can be rerlated to their background knowledge. When students learn to make connections from their experience to the text they are currently reading, they have a foundation, or scaffolding, upon which they can place new facts, ideas, and concepts. As good readers read, they think about what they are reading and consider how it fits with what they already know. In this way, they build upon the schema that they already have developed. "Teaching children which thinking strategies are used by proficient readers and helping them use those strategies independently creates the core of teaching reading." (Keene and Zimmerman, 1997)

\section{BELIEFES ABOUT THE ROLE OF THE TEACHER}

"In essence, the teacher's role is to implement curriculum developed by developers with little or no input of their own. Teachers should be able to make application included in the curriculum to meet students' needs and interests. This will help students to learn, create meanings, and the skills necessary to be fully functioning members of a democratic society." Fundi, Shaaban (2013) With this being said, teacher should take their responsiblities towards their students by manging classroom considering the students interests and needs with out loosing the way to fufill the scoeity needs.

In Saudi Arabia, teachers do not play a significant role in curriculum development. When there is a general call from the Ministry of Education, requesting teacher input, and participation in curriculum development, there is a lack of response. Numerous teachers appear to feel their contributions may prove ineffective due to preconceived positions by the Ministry.

Personally, I disagree with this. I have responded to Ministry inquiries and received very positive responses. On one occasion I was invited to meet with a representative of the Administration Committee for Development of Curricula. During that meeting, I was asked to present my view in depth. I believe that teachers can contribute to curriculum development on their own. I came out of the meeting with the belief that if there is blame to be addressed, it must be shared by everyone in education.

It is important for the teachers to understand that they may incorporate some of their views into the class sessions without affecting the general guidelines of the curriculum, but that if they feel those views definite enough to present to the class, they may be of value in the curriculum. The only way to determine that is to respond to the Ministry when asked. 


\section{IMPLICATIONS FOR YOUR PROFESSIONAL PRACTICE}

The implication for my professional practice is that to involve teachers along with what students can expect from curriculum. I believe that once teachers feel that they are the ones involved in curriculum planning, they will be encouraged to keep evaluating their outcomes and look forwards improvements. Moreover, students, once they are involved in planning curriculum in any way that "would engage the student's love of knowledge, and use that to re-inspire the teacher's, would develop a mature critical self, which was nevertheless sophisticatedly appreciative, would incorporate the Barnett value of dealing with super complex paradigms and value systems while understanding how and why to invest oneself" (Parker, 2003)

\section{What Effect Does my School Curriculum Have upon my Professional Practice?}

As an experienced professional teacher, I feel that the current curriculum in Saudi Arabia has an adverse impact on both myself and my students by not carefully relating objectives with student needs. It was this impact that taught me to study my students and guide them in the best ways to promote their courage, collaboration, and class involvement. I was also able to coach new teachers in what I felt were the best learning skills and how they might employee them to enrich their teaching experience. I believe that the teacher has the leading role where he can adopt the necessary skill sets to meet the school curriculum objectives.

\section{What do I suspect could be done to Improve Curriculum in my School?}

I feel the curriculum in the Saudi school system may be fine-tuned by:

1. Teachers of specific disciplines must coordinate their expertise with regular meetings to share and input curriculum as needed.

2. Teachers take a more proactive role in identifying skill sets and knowledge of students both to assist new faculty and to improve the school curricula.

3. Interscholastic participation on a nationwide basis. The sharing of ideas, lesson plans, theories and more between schools may only serve to better the overall school system.

4. Clarification of the national curriculum objectives with an open mind to revision as needed is a step towards unification of the school system to the advantage of students, faculty and administration.

\section{CONCLUSIONS OF DRAWN IDEAS}

All evidence, from the laboratory and from extensive case studies of professionals, indicates that real competence only comes with extensive practice. By denying the critical role of practice, one is denying children the very thing they need to achieve competence." (Walberg, 2006).

I completely agree with the importance of the application of social efficiency ideology with some especially for growing and developing countries. This ideology relies on both empirical evidence and information. On one hand, the evidence given to critique other theoretical constructs of the curriculum is valuable since it focuses on the real situations of people whose experiences and predicaments must be the source of all ethical concerns. On the other hand, the restriction of curriculum theory to a functional relationship with practice can lead to a better application of the learning procedure. Especially when we realize the relation between curriculum and the wider social context which can be considered subtle and tacit. There is an essential belief that we should resist the temptation of thinking only about the curriculum theoretical basis about the school practice. The value of theory must be aligned with particular practices which pose a threat of continuing curriculum inquiry 
to those very practices which will serve ideological interests. Such a reduction overlooks the normative role which theory can play in compliance with the nature of the curriculum inquiry. In short, human life contains specific knowledge and skills to acquire certain abilities. Learning should serve to prepare for a better life, thus learning must train each student in those skills and knowledge.

Back in Saudi Arabia, It was the philosophy of the Saudi Educational System that pre-college education would be based on specific curriculum and instructional methods in concert with those in global use. The basis of this is a Scholar Academic Ideology in curriculum and a banking model in instruction.

When I began my college education at Al Qassim University, Saudi Arabia, I elected to major in English Instruction and Translation studies. It was at this time that I began to realize there are numerous other methodologies for curriculum development and classroom instruction available for those educators interested in improving the educational system.

Following my graduation, I sought out a position as an English teacher where I could employ the knowledge sets I had gained during undergraduate school. Unfortunately, once I found a position I was almost from the outset, confronted with an "Old School" mentality emanating from my fellow teachers in regards to curriculum development.

The prevailing thinking of the majority of teachers of the period was one of not wanting to change. Unchallenged acceptance of the curriculum established by the Ministry of Education was the norm. This appeared to be supported by a general feeling of protection of Arabic, the "Mother Tongue" to prevent it from being displaced by any other language.

Once I had acquired some years' experience as a teacher and had the opportunity to be exposed to modern technology and the media, my concept of a vast world, began to shrink and become more personal. My thinking changed as did my ideas about education, and schools in general.

I believe that now, with an enhanced understanding of myself, my talents and my dedication to learning, I am better trained and armed to serve the needs of the students, the schools and educational community in general.

\section{I would like to end up with this qutation}

"You cannot teach a language: you can only creat the right conditions for learning it." Wilhelm von Humbildt (1767- 1835).

\section{REFRENCES}

Keene, E.K., \& Zimmerman, S. (1997). Mosaic of thought: Teaching comprehension in a reading workshop. Portsmouth, NH: Heinemann

Foshay, A. W. (summer, 1991). The Curriculum Matrix: Transcendence and Mathematics. Journal of Curriculum and Supervision, Volume 6 | Number 4

Fundi, Ph.D., S. (2016, March 18). Social Efficiency and Learner Centered Ideologies in Education. Retrieved April 11, 2016, from Kobigoji, http://kibogoji.com/author/sfundi1/ 
Inc, Q. (2016). Sign up for an account. Retrieved March 12, 2016, from

Parker, J. (2003). Reconceptualising the curriculum: From commodification to transformation. Teaching in Higher Education, 8(4), 529-543.

Slavin, R.E. (2008). What works? Issues in synthesizing educational program evaluations. Educational Researcher, 37(1), 5-14.

Slavin, R. E. (1987). Ability grouping and student achievement in elementary schools: A best-evidence synthesis. Review of Educational Research, 57, 293-336.

Schiro, M. (2012). Curriculum theory: Conflicting visions and enduring concerns (2nd ed.). Thousand Oaks, CA: SAGE Publications.

Walberg, H. J. (2006). The Scientific Basis of Educational Productivity. Chicago: University of Illinois.

Citation: Ibrahim Alfarhan, Personal Ideology of Curriculum, American Research Journal of Humanities and Social Sciences, Volume 2, pp:1-6

Copyright (c) 2016 Ibrahim Alfarhan, This is an open access article distributed under the Creative Commons Attribution License, which permits unrestricted use, distribution, and reproduction in any medium, provided the original work is properly cited. 